Jurnal Olahraga \& Kesehatan Indonesia

Volume 1 Nomor 1 (2020)

E-ISSN: 2747-061X

available online at https://jurnal.stokbinaguna.ac.id/index.php/jok

\title{
PROFIL KEBUGARAN JASMANI SISWA EKSTRAKURIKULER BOLA VOLI
}

\author{
Ilyas ${ }^{1}$, Ahmad Almunawar ${ }^{2}$ * \\ ${ }^{1}$ MAS Al Washliyah Tanjung Balai, Sumatera Utara, Indonesia, 21362 \\ ${ }^{2}$ STOK Bina Guna, Sumatera Utara, Indonesia, 20241 \\ *Coressponding Author: a.almunawar16@gmail.com
}

\section{Keterangan}

Rekam Jejak:

Received, Oktober 2020

Revised, November 2020

Accepted, Desember 2020

Kata Kunci:

Kebugaran Jasmani, Siswa, Ekstrakurikuler, Bola Voli
Penelitian ini bertujuan untuk mengetahui tingkat kebugaran jasmani siswa yang mengikuti kegiatan ekstrakurikuler bola voli di MAS Al Washliyah Tanjung Balai Tahun 2020 dengan menggunakan Tes Kebugaran Jasmani Indonesia (TKJI). Ada item tes yang dilakukan meliputi tes lari 60 meter, tes angkat tubuh, tes baring duduk, tes loncat tegak, dan tes lari 1200 meter. Penelitian dilakukan di MAS Al Washliyah Tanjung Balai dengan metode deskriptif kuantitatif melalui Tes Kebugaran Jasmani untuk usia 16-19 tahun. Tes ini dilakukan pada siswa yang mengikuti kegiatan ekstrakurikuler bola voli dengan jumlah keseluruhan sampel sebanyak 13 orang. Data yang diperoleh kemudian dikonversikan ke dalam tabel penilaian kebugaran jasmani, kemudian dicari nilai rata-ratanya setiap komponen kebugaran jasmani. Maka dalam penelitian ini diperoleh tingkat kebugaran jasmani dengan rentang hasil 18-21 menunjukkan kategori "Baik" sebanyak 7 orang (53.85\%) dan dengan rentang hasil 14-17 menunjukkan kategori "Sedang" sebanyak 6 orang $(46.15 \%)$. Berdasarkan data yang diperoleh disimpulkan bahwa rata-rata tingkat kebugaran jasmani siswa yang mengikuti kegiatan ekstrakurikuler bola voli di MAS Al Washliyah Gading Tanjung Balai Tahun 2020 dikategorikan "Sedang" dengan nilai 17.38. 


\section{PENDAHULUAN}

Beberapa pendapat dikemukakan para ahli tentang kebugaran jasmani yang biasa disebut physical fitness, antara lain kebugaran jasmani didefinisikan sebagai suatu kondisi yang mencerminkan kemampuan seseorang untuk melakukan tugas sehari-haridengan produktif tanpa mengalami kelelahan yang berarti (Mutohir, 1999). Sejalan dengan pendapat Wahyudi dalam Rahman (2010) yang mengatakan bahwa kebugaran jasmani adalah kemampuan tubuh untuk melakukan tugas dan kegiatan sehari-hari dengan giat tanpa mengalami kelelahan yang berarti serta dengan cadangan energi yang tersedia dia masih mampu menikmati waktu luang dan menghadapi hal-hal darurat yang tidak terduga sebelumnya. Dengan demikian, kebugaran jasmani adalah keadaan dari lebih sekedar sehat atau tidak sakit, setiap orang atau kelompok orang, untuk pekerjaan tertentu, memerlukan dan memiliki tingkat kebugaran jasmani yang berbeda. Melengkapi pendapat diatas Nurhasan (2005) juga menyatakan bahwa kebugaran jasmani dibedakan menjadi dua kelompok, yaitu Kebugaran Jasmani untuk Kesehatan dan Kebugaran Jasmani untuk Prestasi Olahraga. Kebugaran Jasmani untuk Kesehatan yaitu daya tahan, kekuatan otot, daya tahan otot, kelentukan, dan komposisi tubuh. Sedangkan kebugaran jasmani untuk prestasi olahraga yaitu daya tahan, kekuatan otot, daya tahan otot, kelentukan, kelincahan, koordinasi, kecepatan, daya ledak, waktu reaksi dan keseimbangan.

Nthoumani dalam Sarwono (2008) seseorang yang memiliki kebugaran jasmani yang baik akan memiliki kemampuan yang yang baik pula dalam melakukan aktifitas. Kemudian Wahyudi (2000) juga mengatakan bahwa kebugaran jasmani adalah kemampuan tubuh untuk melakukan tugas dan kegiatan sehari-hari dengan giat tanpa mengalami kelelahan yang berarti serta dengan cadangan energi yang tersedia ia masih mampu menikmati waktu luang dan menghadapi hal-hal darurat yang tidak terduga sebelumnya. Setiap individu memiliki tingkat kebugaran jasmani yang berbeda-beda, hal ini tergantung pada kondisi organ-organ tubuh individu tersebut. apabila tingkat kebugaran jasmani baik maka akan ada peningkatan dalam kekuatan, kelentukan, kecepatan, stamina dan lainnya akan ada pemulihan dalam organ-organ tubuh setelah latihan, akan ada ekonomi gerak yang lebih baik pada waktu latihan (Harsono 2003). Kebugaran jasmani seseorang merupakan unsur yang penting dalam kehidupan terlebih lagi bagi para atlet yang berlatih dan juga melakukan aktifitas kerja yang lain sehari-harinya. Sebab aktifitas kerja yang dilakukan setiap individu tidak akan terlepas dari faktor kondisi kebugaran jasmani tubuhnya, dapat dikatakan bahwa kebugaran jasmani adalah hal yang mutlakdimiliki olah setiap manusia yang berkeinginan hidup sehat dan bugar. Kebugaran jasmani seseorang dapat ditingkatkan oleh beberapa faktor, adapun faktor-faktor yang mempengaruhi kebugaran jasmani seseorang antara lain:

Genetika

Faktor genetika merupakan sifat bawaan sejak lahir yang didapat melalui genetik kedua orangtua atau kerabat dekat, adapun pengaruh secara fisiologis faktor genetic yang diturunkan dari orangtua dapat berupa kekuatan otot, daya tahan otot dan komposisi tubuh. Pengaruh lain yang dapat diturunkan adalah jenis otot serabut atau enzimyang berpengaruh langsung pada kapasitas VO2max.

Usia

Seiring perkembangan dan pertumbuhan mulai dari anak-anak sampai dewasa kira-kira umur 20 tahunan, daya tahan akan mengalami peningkatan seperti daya taham kardiovaskular yang akan mencapai puncak antara umur 20-30 tahun, setelah itu akan menurun. Penurunan ini dapat dikurangi dengan melakukan aktifitas jasmani atau olahraga yang teratur dan terbiasa sejak dini

Jenis Kelamin

Jenis kelamin sangat memengaruhi kebugaran jasmani, penekanan ini terjadi pada perbedaan jumlah lemak antara laki-laki dan perempuan, yang berdampak pada transportasi 
oksigen dalam tubuh, dampak itu berupa perubahan pada jumlah VO2 Max. laki-laki lebih sedikit jumlah lemak dalam tubuh yakni $15 \%$ sedangkan wanita $26 \%$.

Aktifitas Fisik

Aktifitas jasmani sangat berpengaruh terhadap kebugaran jasmani seseorang, terlebih lagi memang aktifitas itu memberikan kontribusi langsung pada komponen kesegaran jasmani. Aktifitas fisik tetap harus disesuaikan dengan usia anak, misalnya jenis aktifitas fisik, faktor keselamatan, dan peralatan yang digunakan.

Rutinitas Olahraga

Kebiasaan berolahraga berpengaruh terhadap kebugaran jasamani apalagi intensitas, frekuensi dan lama olahraga yang dilakukan akan sangat berpengaruh. Membiasakan anak-anak berolahraga sangat membantu meningkatkan kesegaran jasmani anak, selain itu melalui kebiasaan olahraga beberapa hal positif dapat membantu anak menyalurkan ekspresi mereka.

Status gizi

Kecukupan zat-zat makanan yang dikonsumsi akan sangat memengaruhi status gizi sehingga orang tersebut akan terlihat kualitas fisiknya demikian juga sebaliknya. Kondisi status gizi yang kurang akan berdampak pada kualitas fisiknya yang artinya berdampak pada kesegaran jasmaninya.

Kadar Hemoglobin

Semakin banyak kadar $\mathrm{Hb}$ dalam darah maka pengangkutan oksigen dalam tubuh untuk disebarkan keseluruh tubuh akan semakin baik, dan ini akan berpengaruh terhadap kebugaran jasmani seseorang.

Status Kesehatan

Orang sehat belum tentu mempunyai tingkat kebugaran jasmani yang baik tetapi orang yang memiliki kebugaran jasmani yang baik pasti sehat. Pernyataan itu tepat sekali bahwa tidak ada satu penyakit dalam diri seseorang bukan berarti mempunyai tingkat kebugaran jasmani yang baik.

Kebiasaan Merokok

Merokok akan berpengaruh langsung pada daya tahan kardiovaskular, hal ini dipengaruhi oleh asap rokok yang dihirup yang mengandung karbondioksida (CO2). Didalam darah ada $\mathrm{Hb}$ yang berperan dalam mengangkut oksigen untuk diedarkan keseluruh tubuh . Bila ada CO2 maka pengangkutan $\mathrm{O} 2$ akan terganggu sebab $\mathrm{CO} 2$ mempunyai tingkat afinitas yang lebih besar dibandingkan O2. Namun, perlu diingat juga yang lebih berbahaya yakni begi perokok pasif, dan itu bisa terjadi pada anak-anak .

Kecukupan Istirahat

Kecukupan istirahat sangat berpengaruh terhadap kebugaran jasmani seseorang. Jika tubuh kita kurang istirahat, maka akan menyebabkan penampilan fisik akan menurun, daya konsentrasi atau yang berkenaan dengan mental akan terpengaruh. Waktu istirahat dan tempat istirahat yang nyaman untuk anak sangat penting diperhatikan, sehingga mereka memiliki kecukupan istirahat yang membantu kebugaran jasmani mereka menjadi semakin baik.

Kebugaran jasmani sangat berperan penting dalam kehidupan sehari-hari tak terkecuali oleh siswa. Berdasarkan dari teori-teori yang telah dikemukanan dalam kerangka teoritis, tampak jelas bahwa untuk meningkatkan kebugaran jasmani sangat perlu dilakukan suatu aktifitas fisik. Oleh sebab itu, di perlukannya pendidikan jasmani sebagai sarana untuk membina peningkatan kebugaran jasmani di dalam dunia pendidikan. Melalui kegiatan ekstrakurikuler sebagai sarana pendukung kebugaran jasmani banyak memberi kontribusi dalam peningkatan kebugaran jasmani pada siswa. Survei kebugaran jasmani yang dilakukan pada siswa yang mengikuti ekstrakurikuler bola voli bertujuan untuk melihat tingkat kebugaran jasmani pada siswa. Dengan mengetahui tingkat kebugaran jasmani siswa, maka peningkatan untuk prestasi akan lebih diperhatikan dengan baik. Dengan melihat tingkat kebugaran jasmani siswa yang ikut serta dalam kegiatan ekstrakurikuler bola voli maka program latihan yang diberikan pada kegiatan itu akan tepat manfaat sesuai dengan kebutuhan. Sebuah kepastian dalam peraihan prestasi dibutuhkan kebugaran jasmani yang prima dan kuat. 


\section{METODE}

Penelitian ini merupakan penelitian survei dimana dalam pelaksanaannya peneliti hanya melaksanakan tes kebugaran jasmani tanpa mengambil data awal (pretest). Hasil dari tes yang dilakukan merupakan kondisi nyata tingkat kebugaran jasmani siswa tanpa adanya perlakuan peningkatan. Maka dari pendapat tersebut penelitian ini menggunakan populasi secara keseluruhan untuk menjadi sampelnya (total sampling) yaitu 13 orang siswa putra yang ikut dalam kegiatan ekstrakurikuler bola voli. Variabel penelitian adalah atribut atau peubah penelitian yang akan diukur, adapun variabel pada penelitian ini adalah variabel tunggal yaitu tingkat kebugaran jasmani pada siswa yang mengikuti kegiatan ekstrakurikuler bola voli pada Al Washliyah Gading Tanjung Balai Tahun 2020. Kebugaran jasmani yang akan di teliti adalah kebugaran jasmani para peserta yang mengikuti kegiatan ekstrakurikuler bola voli sejumlah 13 orang putra dengan mengikuti tes kebugaran jasmani berdasarkan Lokakarya Tes Kebugaran Jasmani Indonesia Tahun 1984.

Penelitian ini menggunakan metode kuantitatif dengan teknik pengumpulan data berupa tes kebugaran jasmani pada anak usia 16-18 tahun (Lokakarya Kebugaran Jasmani 1984). Adapun rangkaian tes yang diambil berupa:

Tes Lari 60 meter

- Tujuan:

Mengukur kecepatan lari seseorang.

- Alat dan fasilitas:

Lintasan lari, bendera start, pluit, stopwatch, garis start/finish, formulir penilaian.

- Pelaksanaan:

- Siswa berdiri di belakang garis start dengan sikap berdiri.

- Apabila ada aba-aba "ya", siswa lari kedepan secepat mungkin menempuh jarak 60 meter.

- Pada saat siswa menyentuh/melewati garis finish, maka stopwatch dihentikan.

- Pengukuran waktu dilakukan dari saat bendera diangkat sampai pelari melintas garis finish.

- Skor adalah hasil yang dicatat adalah catatan waktu pelari (satuan detik) dalam menempuh jarak 60 meter.

Tes Gantung Angkat Tubuh

- Tujuan:

Mengukur kekuatan dan daya tahan otot bahu.

- Alat dan fasilitas:

Lantai datar, palang tunggal, stopwatch, formulir penilaian.

- Pelaksanaan:

- Sikap permulaan: peserta berdiri dibawah palang tunggal. Kedua tangan berpegangan pada palang tunggal (selebar bahu). Pegangan telapak tangan menghadap kearah letak kepala.

- Gerakan: mengangkat tubuh dengan membengkokkan kedua lengan, sehingga dagu menyentuh atau berada diatas palang tunggal kemudian kembali ke sikap permulaan. Gerakan ini dihitung satu.

- Selama melakukan gerakan mulai dari kepala hingga ujung kaki tetap merupakan satu garis lurus.

- Gerakan ini dilakukan berulang-ulang tanpa istirahat sebanyak mungkin selama 60 detik.

- Skor adalah pencatatan hasil yang dihitung adalah angkatan yang dilakukan dengan sempurna dan yang dicatat adalah jumlah angkatan yang dilakukan dengan sempurna tanpa istirahat selama 60 detik.

Tes Baring Duduk

- Tujuan: 
Mengukur kekuatan dan daya tahan otot perut.

- Alat dan fasilitas:

Lantai yang datar, stopwatch, formulir penilaian.

- Pelaksanaan:

- Siswa berbaring telentang diatas lantai/rumput, kedua lutut ditekuk kurang lebih 900.

- Kedua tangan diletakkan dibelakang kepala dengan jari tangan berselang seling dan kedua lengan menyentuh lantai.

- Salah seorang teman memegang atau menekan kedua pergelangan kaki, agar kaki tidak terangkat.

- Pada saat aba-aba "Ya" peserta bergerak mengambil sikap duduk sampai kedua sikunya menyentuh kedua paha, kemudian kembali kesikap semula.

- Gerakan tersebut dilakukan berulang-ulang dengan cepat tanpa istirahat, selama 60 detik.

- Skor adalah hitungan pencatatan yaitu jumlah gerakan baring duduk yang dapat dilakukan dengan benar selama 60 detik dengan sempurna. Setiap gerakan baring duduk yang tidak sempurna tidak dihitung.

Tes Loncat Tegak

- Tujuan:

Mengukur daya ledak otot tungkai.

- Alat dan fasilitas:

Papan berskala centimeter berwarna gelap, berukuran $30 \times 150 \mathrm{~cm}$ yang digantung atau dilekatkan pada dinding rata dengan ketinggian (jarak) antara lantai dan papan skala 0 - 150 $\mathrm{cm}$, serbuk kapur, penghapus papan/kapur, dan formulir penilaian.

- Pelaksanaan:

- Siswa berdiri tegak disamping dinding berskala dengan kaki rapat.

- Tangan yang disamping dinding diangkat keatas lurus dengan menempelkan telapak tangan ke dinding hingga meninggalkan bekas.

- Kemudian siswa mengambil awalan dengan sikap menekukkan lutut dan kedua lengan diayun kebelakang.

- Kemudian siswa meloncat dengan setinggi mungkin sambil menepuk papan dengan tangan yang terdekat sehingga menimbulkan bekas jangkauan pada papan skala. Tes ini dilakukan sebanyak 3 kali berturut-turut.

- Skor adalah hasil loncat tegak diperoleh dengan cara hasil jangkauan tertinggi dari loncatan tersebut dikurangi tinggi jangakaun tanpa loncatan. Contoh: Budi tinggi jangkauan tanpa loncatannya 100, sedangkan tinggi jangkauan loncatannya mencapai $200 \mathrm{~cm}$, maka skor yang diperoleh Budi adalah $200 \mathrm{~cm}-100 \mathrm{~cm}=100 \mathrm{~cm}$. Hitung untuk masing-masing hasil loncatan yang telah diperoleh.

Tes Lari 1200 Meter

- Tujuan:

Mengukur daya tahan jantung.

- Alat dan fasilitas:

Lintasan lari, stopwatch, bendera, garis start/finish, formulir penilaian.

- Pelaksanaan:

- Siswa berdiri di belakang garis start.

- Pada saat aba-aba "siap", siswa mengambil start berdiri.

- Pada aba-aba "ya", siswa mulai berlari menempuh jarak 1200 meter.

- Skor adalah waktu yang dicapai siswa dalam menempuh jarak 1200 meter.

Setelah data dari kelima item tes tersebut didapat, maka langkah selanjutnya adalah melihat norma tes yang dijabarkan berikut ini:

Tabel 1. Norma Tes Kebugaran Jasmani 


\begin{tabular}{|c|c|c|c|c|c|}
\hline Lari 60 Meter & $\begin{array}{c}\text { Gantung Angkat } \\
\text { Tubuh }\end{array}$ & $\begin{array}{l}\text { Baring } \\
\text { Duduk }\end{array}$ & $\begin{array}{l}\text { Loncat } \\
\text { Tegak }\end{array}$ & $\begin{array}{l}\text { Lari } 1200 \\
\text { Meter }\end{array}$ & Nilai \\
\hline s.d - 7,2" & 19 - keatas & $41-$ keatas & 73 - keatas & s.d - 3'14"' & 5 \\
\hline $7,3 "-8,3 "$ & $14-18$ & $30-40$ & $60-72$ & $3^{\prime} 15-4^{\prime} 25$ & 4 \\
\hline $8,4 "-9,6 "$ & $9-13$ & $21-29$ & $50-59$ & $4^{\prime} 26-5 ' 12^{\prime \prime}$ & 3 \\
\hline $9,7 "-11,0 "$ & $5-8$ & $10-20$ & $39-49$ & $5 ' 13^{\prime \prime}-63^{\prime} 33^{\prime \prime}$ & 2 \\
\hline $11,1 "-\mathrm{dst}$ & $0-4$ & $0-9$ & $38-d s t$ & 6'34" - dst & 1 \\
\hline
\end{tabular}

Dari kelima item tes tersebut, maka hasil penjumlahan tiap item akan dikonversikan untuk melihat tingkat kebugaran jasmani siswa.

Tabel 2. Norma Klasifikasi Kebugaran Jasmani

\begin{tabular}{cc}
\hline Jumlah Nilai & Klasifikasi \\
$22-25$ & Baik Sekali (BS) \\
$18-21$ & Baik (B) \\
$14-17$ & Sedang (S) \\
$10-13$ & Kurang (K) \\
$5-9$ & Kurang Sekali (KS) \\
\hline
\end{tabular}

\section{HASIL \& PEMBAHASAN}

Hasil

Pada hasil tes dan pengukuran yang telah dilakukan terhadap sampel penelitian dengan menggunakan Tes Kesegaran Jasmani (TKJI) usia 16-19 Tahun pada siswa ekstrakurikuler bola voli di Al Washliyah Gading Tanjung Balai Tahun 2020 didapatlah deskripsi penelitian dimana Pada item tes lari 60 meter diperoleh hasil minimum 9.00 detik dan hasil maksimum 7.20 detik dengan rata-rata hasil 7.75 detik. Pada item tes gantung tubuh diperoleh hasil minimum 9 dan hasil maksimum 14 dengan rata-rata 10. Pada item tes baring duduk diperoleh hasil minimum 22 dan hasil maksimum 30 dengan rata-rata hasil 22. Pada item tes loncat tegak diperoleh hasil minimum 61 dan hasil maksimum 68 dengan rata-rata hasil 64. Pada item tes lari 1200 meter diperoleh hasil minimum 5.11 menit dan hasil maksimum 3.22 menit dengan rata-rata hasil 4.35 menit. Untuk lebih jelasnya dapat dilihat pada tabel berikut:

Tabel 3. Hasil Tes Kebugaran Jasmani pada Siswa Ekstrakurikuler Bola Voli

\begin{tabular}{cccc}
\hline Item Tes & Minimum & Maksimum & Rata-rata \\
Tes Lari 60 Meter & 9.00 detik & 7.20 detik & 7.75 detik \\
Tes Gantung Tubuh & 9 kali & $14 \mathrm{kali}$ & $10 \mathrm{kali}$ \\
Tes Baring Duduk & $22 \mathrm{kali}$ & $30 \mathrm{kali}$ & $22 \mathrm{kali}$ \\
Tes Loncat Tegak & $61 \mathrm{~cm}$ & $68 \mathrm{~cm}$ & $64 \mathrm{~cm}$ \\
Tes Lari 1200 Meter & $5.11 \mathrm{menit}$ & 3.22 menit & 4.35 menit \\
\hline
\end{tabular}

Berdasarkan hasil tes kebugaran jasmani yang dilakukan pada siswa ekstrakurikuler di Al Washliyah Gading maka diperoleh data hasil penelitian dimana Dari 13 siswa lakilaki yang mengikuti kegiatan ekstrakurikuler bola voli di MAS Al Walshliyah Gading Tahun 2020 maka diperoleh 7 orang siswa (53.85\%) memperoleh rentang nilai $18-21$ dengan kategori tingkat kebugaran jasmani "BAIK", sedangkan 6 orang siswa $(46.15 \%)$ memperoleh rentang nilai 14-17 dengan kategori tingkat kebugaran jasmani "SEDANG". Untuk lebih jelasnya dapat dilihat pada tabel dibawah ini:

Tabel 4. Kategori Tingkat Kebugaran Jasmani pada Siswa Ekstrakurikuler Bola Voli

$\begin{array}{llll}\text { Jumlah Nilai } & \text { Klasifikasi } & \text { Frekuensi } & \text { Persentasi }\end{array}$




\begin{tabular}{cccc}
$22-25$ & Baik Sekali (BS) & 0 & 0.00 \\
$18-21$ & Baik (B) & 7 & 53.85 \\
$14-17$ & Sedang (S) & 6 & 46.15 \\
$10-13$ & Kurang (K) & 0 & 0.00 \\
$5-9$ & Kurang Sekali (KS) & 0 & 0.00 \\
\multicolumn{2}{c}{ Jumlah } & 13 & 100
\end{tabular}

Dalam mengukur tingkat kebugaran jasmani seseorang dapat dilakukan dengan cara tes kebugaran jasmani yang disesuaikan dengan usia dan kebutuhannya. Pada penelitian ini item tes kebugaran jasmani yang di lakukan adalah tes lari 60 meter, tes gantung tubuh, tes baring duduk, tes loncat tegak dan tes lari 1200 meter. Pengambilan hasi dan nilai tes akan berpedoman pada Tes Kebugaran Jasmani (TKJI) untuk usia 1619 tahun. Adapun hasil dari pelaksanaan tes yang sudah dilakukan sebagai berikut:

Tes Lari 60 Meter

Pada item tes ini bertujuan mengukur komponen kecepatan pada diri seseorang, adapun hasil yang diperoleh dapat dilihat pada tabel dibawah ini:

Tabel 5. Data Perolehan Tes Lari 60 Meter pada Siswa Ekstrakurikuler Bola Voli

\begin{tabular}{ccccc}
\hline Rentang & Nilai & Kategori & Frekuensi & Persentasi \\
$0-7,2 "$ & 5 & Baik Sekali (BS) & 1 & 7.69 \\
$7,3 "-8,3 "$ & 4 & Baik (B) & 10 & 76.9 \\
$8,4 "-9,6 "$ & 3 & Sedang (S) & 2 & 15.38 \\
$9,7 "-11,0 "$ & 2 & Kurang (K) & - & - \\
$11,1 "-$ dst & 1 & Kurang Sekali (KS) & - & - \\
\hline
\end{tabular}

Dari tabel tersebut diketahui komponen kecepatan yang diperoleh melalui tes lari 60 meter pada rentang 0 - 72 detik terdapat 1 orang siswa atau $7.69 \%$ dengan kategori "Baik Sekali", pada rentang 7.3 - 8.3 detik terdapat 10 orang siswa atau $76.9 \%$ dengan kategori "Baik", dan pada rentang 8.4 - 9.6 detik terdapat 2 orang siswa atau $15.38 \%$ dengan kategori "Sedang".

Tes Gantung Tubuh

Pada item tes ini bertujuan mengukur komponen kekuatan dan daya tahan otot bahu pada diri seseorang, adapun hasil yang diperoleh dapat dilihat pada tabel dibawah ini:

\begin{tabular}{|c|c|c|c|c|}
\hline Rentang & Nilai & Kategori & Frekuensi & Persentasi \\
\hline $19-$ keatas & 5 & Baik Sekali (BS) & - & - \\
\hline $14-18$ & 4 & Baik (B) & 1 & 7.69 \\
\hline $9-13$ & 3 & Sedang (S) & 12 & 92.31 \\
\hline $5-8$ & 2 & Kurang (K) & - & - \\
\hline $0-4$ & 1 & Kurang Sekali (KS) & - & - \\
\hline
\end{tabular}

Dari tabel tersebut diketahui komponen daya tahan otot bahu yang diperoleh melalui tes angkat tubuh pada rentang $14-18$ terdapat 1 orang siswa atau $7.69 \%$ dengan kategori "Baik", dan pada rentang 9 - 13 terdapat 12 orang siswa atau $92.31 \%$ dengan kategori "Sedang".

Tes Baring Duduk 
Pada item tes ini bertujuan mengukur komponen daya tahan otot perut pada diri seseorang, adapun hasil yang diperoleh dapat dilihat pada tabel dibawah ini:

Tabel 7. Data Perolehan Tes Baring Duduk pada Siswa Ekstrakurikuler Bola Voli

\begin{tabular}{ccccc}
\hline Rentang & Nilai & Kategori & Frekuensi & Persentasi \\
$41-$ keatas & 5 & Baik Sekali (BS) & - & - \\
$30-40$ & 4 & Baik (B) & 1 & 7.69 \\
$21-29$ & 3 & Sedang (S) & 10 & 76.92 \\
$10-20$ & 2 & Kurang (K) & 2 & 15.38 \\
$0-9$ & 1 & Kurang Sekali (KS) & - & - \\
\hline
\end{tabular}

Dari tabel tersebut diketahui komponen daya tahan otot perut yang diperoleh melalui tes baring duduk pada rentang 30 - 40 terdapat 1 orang siswa atau $7.69 \%$ dengan kategori "Baik", pada rentang 21 - 29 terdapat 10 orang siswa atau $76.9 \%$ dengan kategori "Sedang", dan pada rentang $10-20$ terdapat 2 orang siswa atau $15.38 \%$ dengan kategori "Kurang".

Tes Loncat Tegak

Pada item tes ini bertujuan mengukur komponen daya ledak otot tungkai pada diri seseorang, adapun hasil yang diperoleh dapat dilihat pada tabel dibawah ini:

\begin{tabular}{ccccc}
\multicolumn{5}{c}{ Tabel 8. Data Perolehan Tes Loncat Tegak pada Siswa Ekstrakurikuler Bola Voli } \\
\hline Rentang & Nilai & Kategori & Frekuensi & Persentasi \\
$73-$ keatas & 5 & Baik Sekali (BS) & - & - \\
$60-72$ & 4 & Baik (B) & 13 & 100 \\
$50-59$ & 3 & Sedang (S) & - & - \\
$39-49$ & 2 & Kurang (K) & - & - \\
$38-0$ & 1 & Kurang Sekali (KS) & - & - \\
\hline
\end{tabular}

Dari tabel tersebut diketahui komponen daya ledak otot tungkai yang diperoleh melalui tes loncat tegak pada rentang 60 - 70 terdapat 13 orang siswa atau $100 \%$ dengan kategori "Baik".

Tes Lari 1200 Meter

Pada item tes ini bertujuan mengukur komponen daya tahan jantung paru pada diri seseorang, adapun hasil yang diperoleh dapat dilihat pada tabel dibawah ini:

Tabel 9. Data Perolehan Tes Lari 1200 Meter pada Siswa Ekstrakurikuler Bola Voli

\begin{tabular}{ccccc} 
Rentang & Nilai & Kategori & Frekuensi & Persentasi \\
s.d-3'14" & 5 & Baik Sekali (BS) & - & - \\
3'15-4'25 & 4 & Baik (B) & 7 & 53.85 \\
4'26-5'12" & 3 & Sedang (S) & 5 & 38.46 \\
5'13' -6'33" & 2 & Kurang (K) & 1 & 7.69 \\
6'34" - dst & 1 & Kurang Sekali (KS) & - & - \\
\hline
\end{tabular}

Berdasarkan tabel tersebut diketahui komponen daya tahan jantung paru yang diperoleh melalui tes lari 1200 meter pada rentang $3.15-4.25$ menit terdapat 7 orang siswa atau $53.85 \%$ dengan kategori "Baik", pada rentang 4.26 - 5.12 menit terdapat 5 orang siswa atau 38.46\% dengan kategori "Sedang" dan pada rentang $5.13-6.33$ menit terdapat 2 orang siswa atau $7.69 \%$ dengan kategori "Kurang".

\section{Pembahasan}


Setelah pemaparan data hasil tes tersebut maka dapat disimpulkan bahwa secara keseluruhan tingkat kebugaran jasmani pada siswa yang mengikuti kegiatan ekstrakurikuler bola voli di MAS Al Washliyah Gading Tanjung Balai Tahun 2020 memiliki kategori "Sedang" hal ini berdasarkan rata-rata hasil yang diperoleh pada setiap item tes adalah 17.38. Dengan demikian tingkat kebugaran jasmani pada siswa yang mengikuti kegiatan ekstrakurikuler bola voli di MAS Al Washliyah Gading Tanjung Balai dapat ditingkatakan dan belum optimal. Untuk dapat mengoptimalkan kebugaran jasmani dapat ditempuh dengan kedisiplinan dan penjalanan program latihan dengan baik. Bentuk latihan yang konsisten dan berkelanjutan dapat sangat mempengaruhi tingkat kebugaran jasmani seseorang oleh sebab itu diperlukan peran pelatih dan kesadaran berprestasi yang besar bagi siswa dalam meningkatkannya. Adapun komponen kebugaran jasmani yang perlu dilatih pada siswa yang mengikuti ekstrakurikuler bola voli seperti daya tahan jantung paru, daya tahan otot, daya ledak, kekuatan, kecepatan, kelincahan, kecepatan reaksi, keseimbangan dan stamina.

\section{SIMPULAN}

Berdasarkan pada data hasil penelitian yang telah dilakukan melalui tes kebugaran melalui tes dan pengukuran terhadap siswa ekstrakurikuler bola voli di Al Washliyah Gading Tanjung Balai Tahun 2020 yang mengacu pada Tes Kebugaran Jasmani Indonesia untuk usia 16-19 tahun maka diperolehlah kesimpulan bahwa tingkat kebugaran jasmani pada siswa ekstrakurikuler bola voli di Al Washliyah Gading Tanjung Balai Pada Tahun 2020 memiliki kategori "Sedang" dengan rata-rata hasil perolehan tes 17,38 .

\section{DAFTAR PUSTAKA}

Agustin, Era. (2012). Survei Tingkat Kebugaran Jasmani Pada Siswa Tsanawiyah Yang Berada Di Pondok Pesantren Modern Darul Hikmah Taman Pendidikan Islam (PPMDH TPI) Tahun Ajaran 2012/2013. Skripsi, UNIMED.

Ahmadi, Nuril. (2007). Panduan Olahraga Bola Voli. Surakarta: Era pustaka.

Arikunto, Suharsimi. (2010). Prosedur Penelitian. Jakarta: PT. Rineka Cipta.

Departemen Pendidikan Nasional. (1984). Tes Kebugaran Jasmani Indonesia. Jakarta: Pusat Kesegaran Jasmani dan Rekreasi.

Hadi, Sutrisno. (1981). Statistik Jilid II. Jakarta: Penerbit Psikologi UGM.

Harsono. (2003). Coaching dan Aspek-Aspek Psikologis dalam Coaching. Jakarta.

Harsuki. (2012). Pengantar Menajemen Olahraga. Jakarta: PT. Raja Gravindo Persada Jakarta

Efendi, Said. (2000). Pembinaan Olahraga Prestasi Indonesia. Medan: Yayasan Pola Pengembangan Daerah Medan.

Muhajir. (2004) Pendidikan Jasmani. Jakarta: Penerbit Yudistira.

Nurhasan. (2005). Latihan Kondisi Fisik. Jurnal IPTEK Olahraga; Volume 2, Nomor 2.

Rahman, Aulia. (2010). Survei Kebugaran Jasmani Atlet Gulat Binaan DISPORA Serdang Bedagai Tahun 2009. Skripsi, UNIMED.

Sudjana. (2002). Metoda Statistika. Bandung: Penerbit Tarsito.

Toho Cholik Muthohir. (1999). Standarisasi Kesegaran Jasmani Atlet. Jurnal IPTEK Olahraga, Volume 1, Nomor 2.

Winarno. (1984). Penelitian Masyarakat. Surabaya: Usaha Personal. 